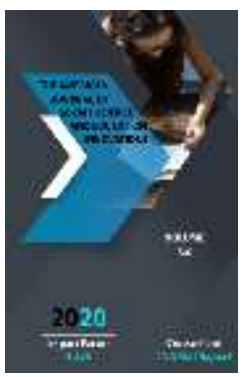

\title{
Mahmud Zamakhshari's Work “Atwoqu-Z-Zahab" Is A Unique Example Of The Development Of Didactic Heritage
}

M.M. Sherova

PhD Student, International Islamic Academy Of Uzbekistan

Journal Website: http://usajournalshub.c om/index,php/tajssei

\section{ABSTRACT}

This article discusses the importance of Mahmud Zamakhshari's work "Atwoqu-z-zahab" in the didactic heritage, the fact that the work has been translated, studied and commented on by world and Uzbek scholars. The articles of the work reflect the important role of moral norms in the development of society.

\section{KEYWORDS}

Didactics, teaching, general features of education, source, interpretation, generosity, value of time.

\section{INTRODUCTION}

It is known that the word didactics means "instructor" in Greek didactics and "learner". Didactics was introduced in Germany in 1613. It was during this period that Christoph Helvich and Joachim Jung wrote a short account of the work of the famous linguist Wolfgang Rathke (1571-1635)"A Short Account of Didactics or the Art of Studying Ratichia". According to Jan Amos Comenius, didactics reflects not only teaching but also upbringing. It explains the necessary conditions of high spirituality aimed at the formation of morality [1, 14-15].

Abu al-Qasim Mahmud ibn Umar Zamakhshari, a mature figure of the land of ancient Urgench, a scholar, encyclopedic scholar, holder of the title "Honor of Khorezm", wrote "Atwaqu-zZahab fi-l-mawawiz va-l-khutab", which is distinguished by its scientific and moral significance. - The work "Golden Pillars of Teaching and Exhortation" also contains all the norms of morality in the didactic spirit, the 
general features of education, the flower of creation, human dignity, spiritual and enlightenment, religious and secular world, and all the important advice for the public. is a unique complex of the period.

The peculiarity of this rare source is that writers from different countries and different periods who studied it were inspired by the work and wrote new works. They too have earned a worthy place in the treasury of human spiritual history. The great scholars Sharafiddin Isfahani, Muhammad Amin ibn Ibrahim Hanafi Qadiri, Ahmad Shavqi, Mirza Yusufkhan ibn Etisom Malik were influenced by "Atwoqu-zzahab" and wrote masterpieces on special teachings.

\section{THE MAIN FINDINGS AND RESULTS}

This is the story of Mirza Yusufkhan al-Ashtiani, who wrote a commentary on "Atwoqu-zzahab". "Al-Zamakhshari wrote this work during the circumambulation of Makkah. For example, after circumambulating the House, he wrote one article after each circumambulation, then recited it again, and thus, after circumambulating it a hundred times, one hundred articles were written.[2. 79]"

Atwoqu-z-zahab has been translated into several languages. In particular, a German translation of von Josep von Hammer of Arabic origin was published in Vienna in 1835 in Leipzig in the same year, and Gustav File published another German translation in Stuttgart in 1863 (in some publications in 1836). A French orientalist, Barbe Maynard, was also interested in "Atwoqu-z-zahab"and published his French translation in 1876 in Paris. Also, a Turkish translation of the work was published in Constantinople in $1288 \mathrm{AH}$ [2. 79].

In his articles, Mahmud Zamakhshari not only sharply criticized the followers of philosophy, science and the tyrants, but also the scholars who were greedy for wealth, writes openly about social ills, corrupt judges, writers, and even the vicious embezzlement among scholars even today.

In the fourteenth article of the essay, the author emphasizes that time is one of the most precious, great blessings of God, which is worth nothing today, and that a person is responsible for every moment of his life.

He explains the need to live in neglect and indifference, to walk indifferently and the inevitable death of every living being. In addition, on the Day when the good and bad deeds of man are accounted for, the revelation of the deeds of the nomai, the fact that all the deeds, large and small, are written on the pages of the deeds, are impressive, and explain the laws and rules necessary for mankind in every age.

The sages say, "The meaning of life is that one should live to the end of one's life!" Because old age comes suddenly, as if it were snowing. "When you wake up in the morning, you see that everyone is white or that there are dead people who live longer than the living. But there are living beings who are more dead than dead people."

As the poet wrote:

Umr yo'I deydilar, manzili yiroq, Bunda ham dard, ham baxt bo'larkan biroq. Turtinib-surtinib yetgan manziling Qarichgina yeru bir uyum tuproq.

They say the way of life, the address is far, But there is both pain and happiness.

Pushing address -

A pile of soil.

Umr - bir yo'Isanki, manziling sarob, Shamoldek tog'larni kezib o'tarsan. 
Do'l bo'lib bog'larni esib o'tarsan, Ko'zimni yumsamu ochgunga qadar, Bir zumda, bir pasda tugab ketarsan [3. 4-5].

Life is a journey, your address is a mirage, You travel through the mountains like the wind.

When you hail the gardens, Until I close and open my eyes, You end up in an instant, in a pass.

Indeed, time is one of the incomparable blessings, and not wasting a measured life is one of the processes involved in one's spiritual upbringing.

The twentieth article of "Atwoqu-z-zahab" emphasizes that courage is a great quality, that generosity is a great quality, that generosity is one of the ugly vices, and that only the people of generosity deserve friendship and brotherhood. The Uzbek scholar Rashid Zahid, in his translation, called this article "Being good-natured" and commented on it as follows:

Muruvvat go'zal xulqqa xos alomat, Axloqiy poklikka erur dalolat.

Olloh roziligin qozonay desang, Kam bo'Imassan, shu xislatni qil odat.

Mercy is a sign of good behavior,

It is a sign of moral purity.

If you want to gain Allah's approval,

If you are not low, make this habit

Qancha qilinsa oz saxovat vasfi, Olgan qo'Idan baland berganning dasti.

Xolis himmat ochar saodat bobin, Himmatsiz kimsadir odamning pasti.

The less generous you are, The hand of the giver higher than the hand he receives.

Happiness chapter, which opens sincere devotion,
Someone who is ruthless is inferior to man.

Bilsang, saxovat xasta dilga malham, Birodarlik rishtasin aylar mahkam.

o'amgin dilni shod etishning savobi

Ka'bani tavof qilgandan emas kam.

If you know, generosity is an ointment for the sick heart, The bond of brotherhood is firm.

The blessing of rejoicing the heart of the afflicted

Not less than circumambulating the Ka'bah.

Uzoqdagi ne'matni qilsang yaqin, Demak, ado qilding muhtojning haqin

Shunda sendan balo qochib uzoqqa, Muroding yo'li bo'lg'ay ravon, yorqin [4. 26]. If you do a distant blessing, it is near, So you have fulfilled the right of the needy.

Then trouble will flee from you, The road to your destination is smooth and bright

The other articles of the work are also based on such a richness, meaningful teachings and indepth expression of didactic factors that are important for human development. Written using the knowledge, experience and talent of Mahmoud Zamakhshari many centuries ago, this work has been published in various countries around the world since its inception as a unique source. One of his rare manuscripts is kept in the Oriental Studies Fund of the Russian Academy of Sciences, another copy is kept in the Hamid Suleiman Foundation of the Abu Rayhon Beruni Institute of Oriental Studies of the Academy of Sciences of the Republic of Uzbekistan [5. 73].The commentary on the work, written by Mirza Yusufkhan al-Ashtiani, entitled "Qalaid ul-adab fi sharh "Atwoqu-zzahab"” ("Masterpieces of etiquette in the commentary of Atwaqu-z-zahab"), also 
contains a hundred articles on ethics, judgment, and tafsir. Etisami finished writing it at the age of 25 and published it in $1328 \mathrm{AH}$ in the Tamaddun (Culture) publishing house [6]. A copy of the commentary is currently in the library of the Islamic Council [1. 12], another lithograph was donated by Ismail Hakki Bey to the Sulaymaniyah Library in Istanbul in 1921 [7]. The recognition by world scientists and writers of the work of Mahmud Zamakhshari "Atwaquz-Zahab fi-l-mawawiz va-l-khutab" is a striking product of the historical and literary process. Didactic texts, sources, works, literature, textbooks are too many, but the remarkableness of Mahmud Zamakhshari's didactic views is that the author substantially expresses the problems of social, economic, spiritual, enlightenment life of society. It summarizes the didactic norms that reveal the educational, moral world, leading a person to enlightenment, goodness, inner beauty, justice, truth. This impeccable work, embodying the relationship between society and the individual, is an important source of human happiness in both worlds. After all, the role of the ideal person in the development of society and the country in the eyes of future generations is incomparable.

Mahmud Zamakhshari's work "Atwaqu-zZahab fi-l-mawawiz va-l-khutab" was studied in Uzbekistan only during the years of independence. The work was translated into Uzbek by Uzbek scholars Sheikh Abdulaziz Mansur, Rashid Zahid, Mahkam Mahmud, Nazarbek Rahim. These translations have a unique place in our didactic heritage, in Uzbek literature.

Mahmud Zamakhshari's scientific legacy, including "Atwaqu-z-Zahab fi-l-mawawiz va-Ikhutab", is one of the rare examples of didactic literature. This source and the works written under his influence are among the important sources of our didactic heritage and literature.

\section{REFERENCES}

1. Kupisevich, Cheslov. Fundamentals of General Didactics. Moscow: Higher school. 1986. -pp. 12-14-15.

2. Abu-I-Qasim Mahmud az-Zamahshari. Subtle phrases / Commentary and translator U.Uvatov. Tashkent: Kamalak. 1992. -p. 79.

3. The value of time. Tashkent Islamic Institute named after Imam al-Bukhari "Department of Religious Sciences". Prepared by: Azamkhan Muhammadali. "Transoxiana" Tashkent: 2005. -pp. 4-5.

4. Rashid Zahid. Zamakhshar tasbeeh or 101 manzuma. Toshkent: 2011. -p. 26.

5. Institute of Oriental Studies named after Abu Rayhon Beruni of the Academy of Sciences of the Republic of Uzbekistan. Abstracts of the Scientific Conference of Young Orientalists named after Academician Ubaydulla Karimov. Tashkent: 2006. -p.73.

6. www.jalit.ut.ac.ir 5. ص. Nasser Mohseni Nia. Etesam-ol-Molk (Etesami) in both Persian and Arabic literature. Qazvin 2013

7._suleymaniye@yek.gov.tr

8. Goretsky V.G. and others. "Didactic material for literacy lessons". 1982.

9. Okon Vincents. Introduction to general didactics. Moscow: Higher School. 1986.

10. Krachkovskiy I.Yu. Selected works M. L. USSR FA edition. 1960.

11. Karimov N.R. The contribution of Bernd Radtke on the studying Hakim Tirmidhi's scientific heritage. European Journal of Research, 1/12, 2019. - pp. 95103. 